San Jose State University

SJSU ScholarWorks

Master's Theses

Master's Theses and Graduate Research

Fall 2010

\title{
ABSENCE OF KERATIN 8 IS ASSOCIATED WITH MARKED COLON MAST CELL INFILTRATION
}

Diana El Bezri Nasser

San Jose State University

Follow this and additional works at: https://scholarworks.sjsu.edu/etd_theses

\section{Recommended Citation}

Nasser, Diana El Bezri, "ABSENCE OF KERATIN 8 IS ASSOCIATED WITH MARKED COLON MAST CELL INFILTRATION" (2010). Master's Theses. 3879.

DOI: https://doi.org/10.31979/etd.6rsp-cmee

https://scholarworks.sjsu.edu/etd_theses/3879

This Thesis is brought to you for free and open access by the Master's Theses and Graduate Research at SJSU ScholarWorks. It has been accepted for inclusion in Master's Theses by an authorized administrator of SJSU ScholarWorks. For more information, please contact scholarworks@sjsu.edu. 


\title{
ABSENCE OF KERATIN 8 IS ASSOCIATED WITH MARKED COLON MAST CELL INFILTRATION
}

\author{
A Thesis \\ Presented to \\ The Faculty of the Department of Biological Sciences \\ San José State University \\ In Partial Fulfillment \\ of the Requirements for the Degree \\ Master of Physiology \\ by \\ Diana E. Nasser \\ December 2010
}


(C) 2010

Diana E. Nasser

ALL RIGHTS RESERVED 
The Designated Thesis Committee Approves the Thesis Titled

ABSENCE OF KERATIN 8 IS ASSOCIATED WITH MARKED COLON MAST CELL INFILTRATION

by

Diana E. Nasser

APPROVED FOR THE DEPARTMENT OF BIOLOGICAL SCIENCES

SAN JOSÉ STATE UNIVERSITY

December 2010

Dr. Daniel Holley Department of Biological Sciences

Dr. Michael Sneary Department of Biological Sciences

Dr. Aida Habtezion Department of Medicine- Stanford University 


\begin{abstract}
ABSENCE OF KERATIN 8 IS ASSOCIATED WITH MARKED COLON MAST CELL INFILTRATION

by Diana E. Nasser
\end{abstract}

Patients with inflammatory bowel disease (IBD) have increased numbers of numbers of intestinal mast cells (MCs). Chymases and tryptases are mast-cell-specific proteases (MCPs) that are reliable indicators of MC degranulation. The role of MCs in the pathophysiology of IBD is poorly understood, and it is unclear whether MCs play a role in patients or in experimental models of IBD. Furthermore, MCs have been characterized only in chemically induced models of colitis. In this study, we characterize MCs in inflamed colons of keratin 8 knock-out mice (K8-/-), a spontaneous model of colitis with primarily an epithelial cell defect. We used histologic, quantitative PCR (qPCR) and western blot analysis to quantify the increase in MCs and MCPs. Using chloroacetate esterase (CAE) tissue staining, we showed a statistically significant increase $(\mathrm{p}<0.05)$ in MCs in the colon of K8-/- mice as compared to their wildtype littermates, 2,4-dinitrofluorobenzene (DNFB)-treated, and dextran sodium sulfate (DSS)treated mice colons. K8-/- colons showed an increase in all MCPs tested (MCP-1, -2, -4, $-5,-6$, and -7$)$. In addition, at the protein level, both chymase and tryptase were overexpressed in K8-/- colons. In conclusion, absence of K8 was associated with a chronic colitis and with marked MC infiltration. Consistent with the increase in MCs, increased expression of MCPs were noted at the mRNA and protein levels. K8-deficient mice provide a model for studying the role of MCs in IBD. 


\section{ACKNOWLEDGEMENTS}

We thank Robert Oshima (The Burnham Institute, La Jolla, California, USA) and Hélène Baribault (Amgen, South San Francisco, California, USA) for providing the K8-/mice, Evelyn Resurreccion and Jean Chen for assistance with tissue sectioning and RTPCR, respectively. 


\section{TABLE OF CONTENTS}

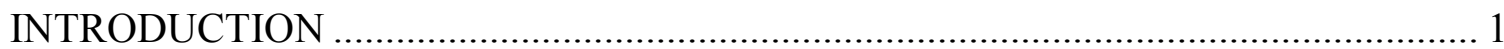

MATERIALS AND METHODS

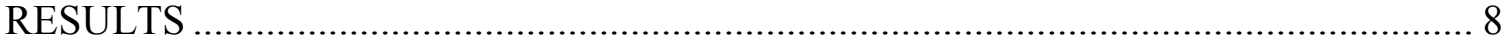

Absence of $\mathrm{K} 8$ is associated with increased number of MCs in the colon. ................... 8

K8-null mice have higher expression of colon MC proteases ................................. 14

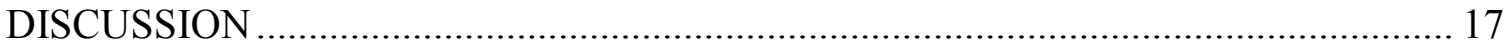

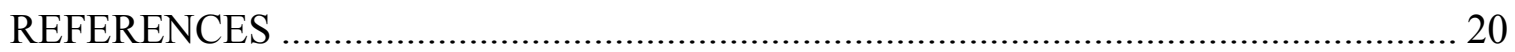




\section{LIST OF TABLES}

TABLE 1: Expression of MC proteases by different MC subclasses in mice............2

TABLE 2: Primers used for real time RT-PCR .................................... 


\section{LIST OF FIGURES}

FIGURE 1: Balb/c mice with chemically-induced colitis lose weight over time .........9

FIGURE 2: Hematoxylin and Eosin (H\&E) staining of colitis and control mice colons.. 10

FIGURE 3: Mast cell (MC) identification using CAE staining ........................13

FIGURE 4: RT-PCR analysis of mast cell protease in K8+/+ and K8-/- mice colons.....14

FIGURE 5: Colon expression of chymase and tryptase level between colitis models.....16 


\section{LIST OF ABBREVIATIONS}

- DSS: Dextran sodium sulfate

- DNFB: 2,4-dinitrofluorobenzene

- IBD: Inflammatory bowel disease

- K8: Keratin 8

- MC: Mast cell

- MCP: Mast cell protease 


\section{Introduction}

Mast cells (MCs) are versatile cells that contain numerous secretory granules in the cytoplasm [1]. They are derived from hematopoietic progenitor cells in the bone marrow, where they initiate their maturation process [2]. MCs do not ordinarily circulate in mature form. They undergo maturation and differentiation after migrating to virtually all vascularized tissues [3]. MCs are abundant in organs highly exposed to exogenous and foreign molecules like the skin, gastrointestinal (GI) tract, and respiratory organs [4]. MCs are particularly plentiful around blood vessels and nerve endings in all of these different tissue types [5] and are known as key players in type I hypersensitivity reactions [6]. On the other hand, MCs have been shown to be involved in a wide range of non-IgEmediated inflammatory or non-allergic diseases including rheumatoid arthritis and cardiovascular diseases [7]. The activation of MCs leads to degranulation and the release of preformed inflammatory mediators such as cytokines, histamine, serglycin proteoglycans, and several MC-specific proteases such as tryptase, chymase and carboxypeptidase A (CPA) [8]. Upon activation, MCs can release their mediators to fulfill their biological functions.

The classification of rodent MC subtypes has been based on phenotypical differences between connective tissue MCs (CTMC) and mucosal MCs (MMC) [9]. CTMCs are found particularly in the skin, peritoneal cavity, and intestinal submucosa, whereas MMCs are found in the intestinal lamina propria [9]. As summarized in Table 1, MMCs mainly express two chymases, mouse MC protease-1 (mMCP-1) and mMCP-2 [10], but do not express tryptase or MC-CPA. However, CTMCs express three 
chymases, mMCP-4, mMCP-5 [11, 12] and mMCP-9 [13] and two tryptases, mMCP-6 and mMCP-7 [11,12]. Each mMCP exhibits a tissue-specific distribution. For example, the mMCP-6 gene is highly expressed in connective tissue mast cells but not in mucosal mast cells [12], whereas mMCP-1 and -2 are restricted to mucosal mast cells [14, 15]. MMC and CTMC appear to differ in morphology and histochemical characteristics as well as many other aspects pertaining to natural history, function, and biochemistry [16, 17]. The most attractive marker for MC subpopulations is the cytoplasmic granule protease content or "phenotype" [9], and the evidence for the presence of MCs is based on finding distinct protease patterns in MCs in different tissues [18]. Chymases and tryptases provide important insights into the unique functions of mast cells because these granule-associated neutral proteases are restricted to MCs [19]. Based on these MCPs, we characterized the presence of colonic MCs in the K8-/- colitis model using chymase and tryptase antibodies.

Table 1. Expression of MC proteases by different MC subclasses in mice

\begin{tabular}{lll}
\hline & Chymase & Tryptase \\
\hline CTMCs & mMCP-4, -5, -9 & mMCP-6, -7 \\
MMCs & mMCP-1, -2 & --- \\
\hline
\end{tabular}

CTMCs: connective tissue mast cells; MMCs: mucosal mast cells.

Inflammatory bowel disease (IBD) is an idiopathic disease characterized by intestinal inflammation [20]. The exact etiology of IBD remains unknown but is thought 
to be a complex interaction of genetic, environmental (e.g., luminal microflora), and immunological factors $[20,21]$. IBD can be subdivided into two major diseases: Crohn's disease (CD) and ulcerative colitis (UC). Although sometimes the two diseases are hard to distinguish when the disease involves the colon, inflammation can occur anywhere along the gastrointestinal tract in CD but is limited to the colon in UC. In addition, there are key histopathologic features that can be used to distinguish between the two forms of IBD.

Several animal models of IBD have been described mostly via genetic targeting of the immune system or via application of chemical injuries [21, 22]. Other models, such as the keratin $8(\mathrm{~K} 8)$ model of colitis, have a primary epithelial cell rather than cytokine or leukocyte defect $[23,24,25]$. Whether mast cells (MCs) play a role in the pathogenesis of IBD is not clear. Moreover, MCs remain poorly characterized in IBD patients and experimental models of colitis [8]. Rijnierse and co-workers [28] propose that MCs play a crucial role in the development of colonic hypersensitivity reaction in the 2,4- dinitrofluorobenzene (DNFB)-induced murine model of IBD. In contrast, MCs are thought not to play a role in the dextran sodium sulfate (DSS)-induced colitis model [26]. Since MCs are likely to play a role in allergic or drug-mediated responses, in this study we characterized MCs in the non-chemical-induced spontaneous K8 model of colitis. 


\section{Materials and Methods}

Mice

K8-/- mice in FVB/n background were kindly provided by Robert Oshima (The Burnham Insitute, La Jolla, California, USA) and Helene Baribault (Amgen, South San Francisco, California, USA). K8-/- mice and their wild-type littermates were generated by interbreeding of $\mathrm{K} 8+/$ - mice under specific pathogen-free environment. Mice were genotyped using tail DNA and PCR [23]. Twelve to sixteen week old gender matched K8 mice were studied. The study was approved by the institutional animal care and use committees.

\section{Immunoblotting analysis}

For immunoblotting, tissues were homogenized using a Teflon homogenizer in a buffer containing $0.187 \mathrm{M}$ Tris-HCL, 3\% SDS, and 5mM EDTA, and the protein concentration was measured using the BCA protein assay (Pierce Chemical, Rockford, Illnois, USA) [27]. SDS-PAGE was done using 10\% acrylamide gels. Equal amounts of proteins were separated by SDS-polyacrylamide gel electrophoresis, transferred to polyvinylidene difluoride membranes, followed by blocking with 5\% nonfat dry milk. The membranes were next incubated with antibodies, washed with PBS/Tween, incubated with peroxidase-conjugated goat anti-mouse, anti-rabbit, or anti-rat immunoglobulins. Immune-reactive bands were visualized using enhanced chemiluminescence (PerkinElmer Life and Analytical Sciences, Boston, Massachusetts, USA). 
Antibodies

The following primary antibodies (Abs) were used in the study: mouse antitryptase (Abcam, Cambridge, Massachusetts, USA), mouse anti-chymase (Abcam, Cambridge, Massachusetts, USA), rat anti-K8 (Troma-1; Developmental Studies Hybridoma Bank; Iowa City, Iowa, USA) and mouse anti-actin (NeoMarkers, Fremont, California, USA). Secondary anti-mouse and anti-rat peroxidase Abs were from SigmaAldrich, St. Louis, Missouri, USA.

Histology

Freshly isolated colons from $\mathrm{K} 8+/+$ and $\mathrm{K} 8-/-$ mice were embedded in optimum cutting temperature (OCT) compound and frozen at -80 C. Serial sections of $6 \mu \mathrm{m}$ were cut using a microtome (Leica) and stained for Hematoxylin and eosin (H\&E). A chloroacetate esterase staining kit (CAE; Sigma-Aldrich) was used to detect mast cells as per manufacturer guidelines as described [28].

Induction of colitis

Colonic hypersensitivity was induced as described previously [28]. Briefly, mice were sensitized on day 0 by application of $50 \mu 1$ of either DNFB $(0.6 \%$ in acetone:olive oil, 4:1) or vehicle (acetone:olive oil, 4:1) epicutaneously on the shaved abdomen, and 50 $\mu 1$ divided over 4 paws. On day 1 , the mice were given a boost of $50 \mu 1$ DNFB or vehicle only on the abdomen. On day 5 , all the animals were challenged intrarectally with $50 \mu 1$ dinitrobenzene sulfonic acid (0.6\% DNS) dissolved in $10 \%$ ethanol. The sensitization, 
boost and challenge took place under light inhalation anesthesia (isoflurane). At day 8 , all mice were sacrificed by $\mathrm{CO}^{2}$ inhalation. Colitis was induced in another group of mice by adding $5 \mathrm{~g}$ of dextran sodium sulfate (DSS) to $100 \mathrm{ml}$ of its drinking water. Control mice were given access to water without DSS. Mice were sacrificed on day 8 .

\section{Quantitative RT-PCR}

Total colon RNA was isolated using an RNeasy midi kit and converted into cDNA using a Superscript II reverse transcriptase kit as recommended by the manufacturer (Invitrogen, Carlsbad, California). Quantitative PCR was performed with an ABI Prism 7900 Sequence Detection System (Applied Biosystems, Foster City, California) as described in Tao, et al. [29]. Target genes were amplified using specific primers (Table 2) and SYBR Green PCR Master Mix (Applied Biosystems). Gene expression levels were normalized to the housekeeping gene GAPDH.

\section{Statistical analysis}

Student's $t$-test was used to determine statistical significance and a $P$ value of less than 0.05 was considered significant. Values are expressed as mean \pm s.e.m. Results shown are from at least 3 independent experiments. 
Table 2. Primers used for real time RT-PCR

\begin{tabular}{lll}
\hline Gene $^{a}$ & Primer & Reference \\
\hline mMCP-1 & & \\
& & 31 \\
mMCP-2 & 5'-GGAAAACTGGAGAGAAAGAACCTAC & 31 \\
& 5'-ATTCATTGGCTAGTTCCTCTGAC & 31 \\
mMCP-4 & 5'-CAGGATGAGAACAGGCTGGGAT & 31 \\
& 5'-GTAATTCCTCTGCCTCGTCCTTC & \\
mMCP-5 & 5'-GGACAGGATGGACACATGCTTT & 31 \\
& 5'-GGCAGAACAAACGTGAATGAGCC & \\
mMCP-6 & 5'-AAGAACCTTCTGGAAGCTCAGGG & 32 \\
mMCP-7 & 5'-CTGGCTAGTCTGGTGTACTCA & \\
& 5'-CAGGGCCACTTACTCTCAGAA & 32 \\
& 5'-GCCAATGACACCTACTGGATG & \\
\hline
\end{tabular}

a mMCP: mast cell protease. mMCP-1,-2,-4 and -5 belong to the chymase group. mMCP- 6 and -7 belong to the tryptase group. 


\section{Results}

\section{Absence of $\mathrm{K8}$ is associated with increased number of MCs in the colon}

Since MCs were shown to increase in number and play a role in DNFB-induced colitis [28], but not in DSS-induced colitis [26], we used both chemically-induced colitis models as reference comparisons for the K8-/- model of colitis. As expected, induction of colitis with DNFB and 5\% DSS led to significant weight loss (Figure 1A\&B) and histologic evidence of colitis (Figure 2). As reported previously, K8-/- mice did not lose weight as compared to K8+/+ littermates [25].

Figure $1 \mathrm{~A}$

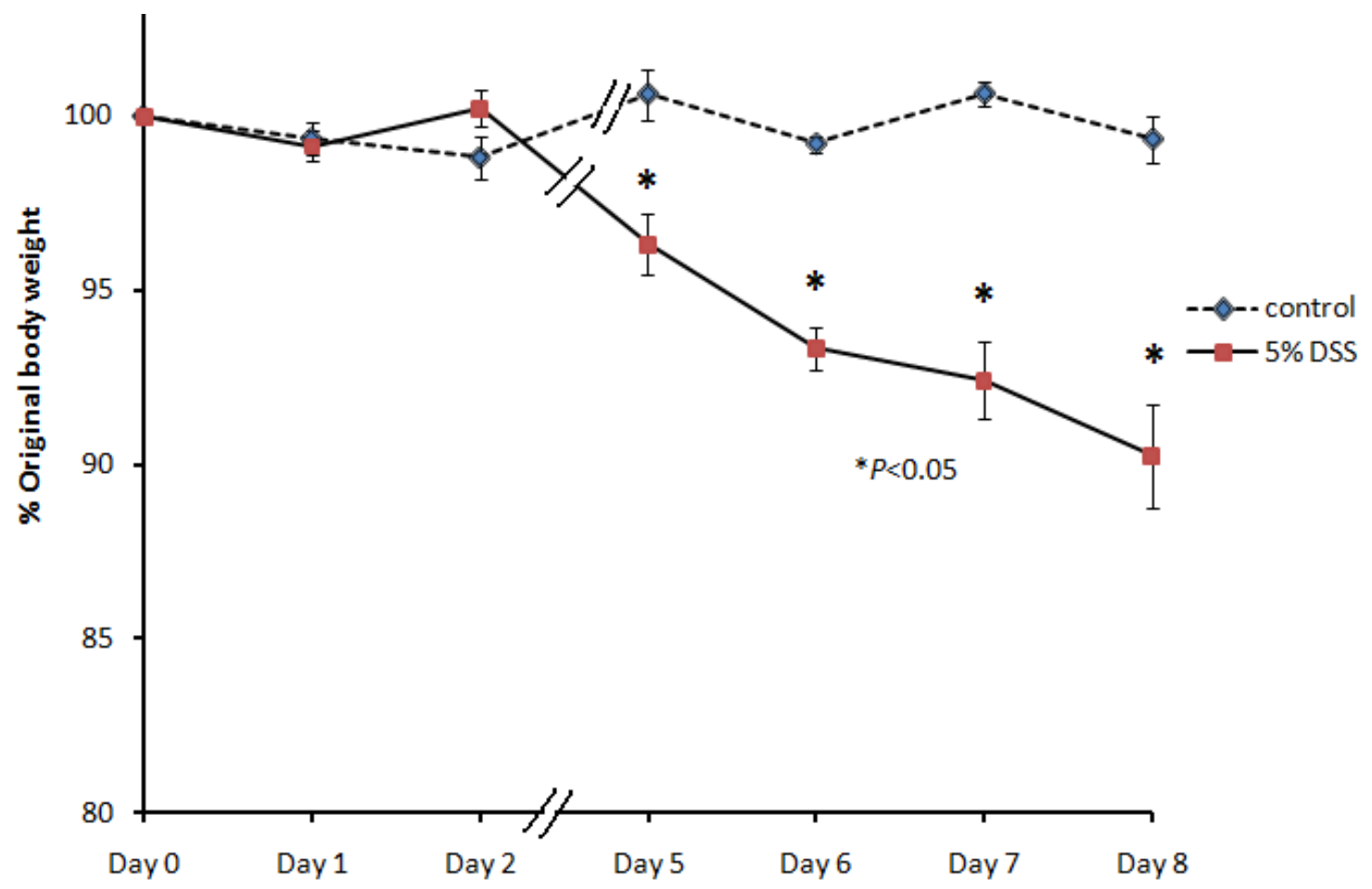


Figure $1 \mathrm{~B}$

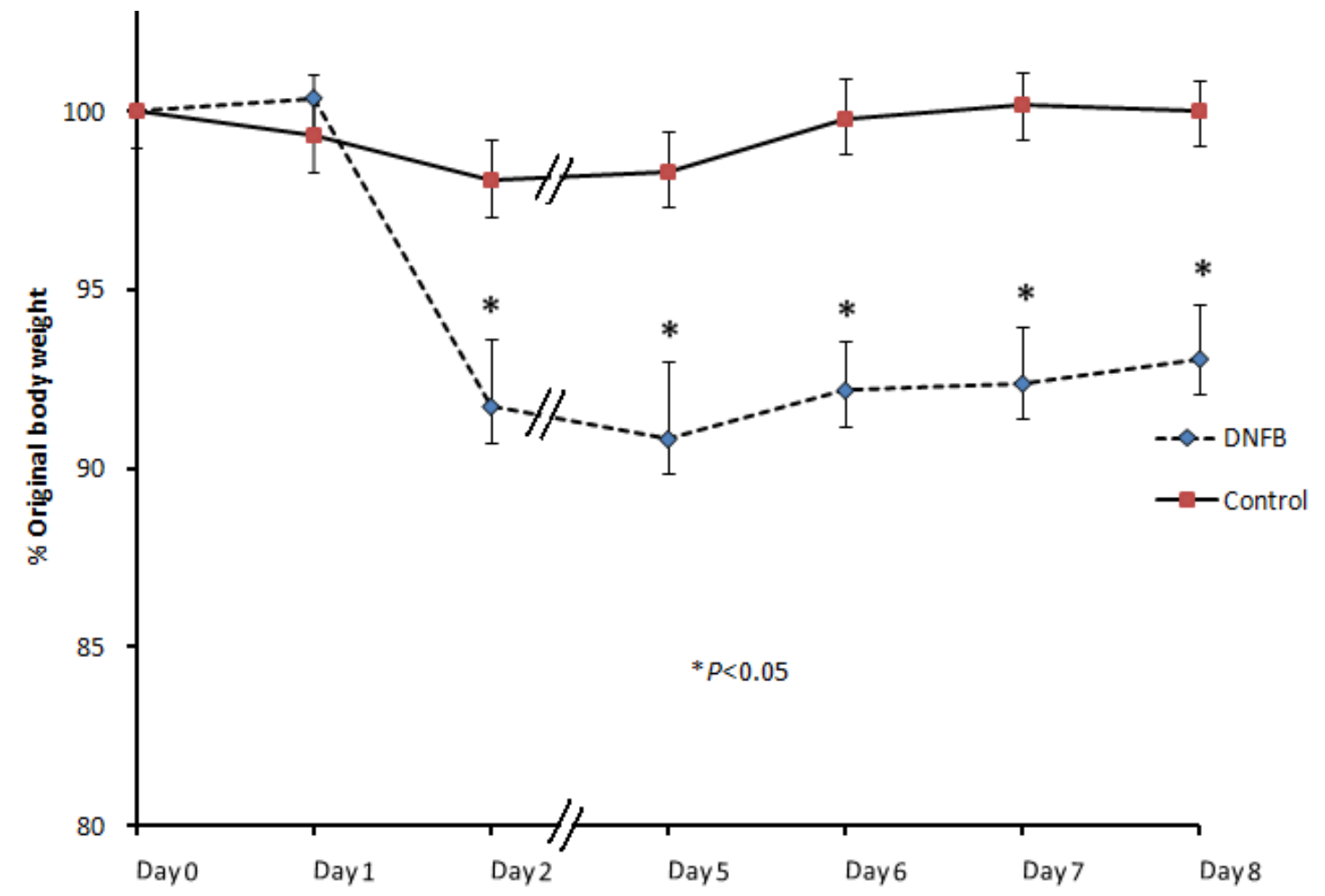

Figure 1. Balb/c mice with chemically induced colitis lose weight over time. The body weight of 5\% DSS-treated control mice (A) and DNFB-sensitized and control mice (B) was monitored, and the $\%$ weight loss was calculated. Data shown are mean \pm s.e.m. for 5 mice per group. ${ }^{*} \mathrm{p}<0.05$ 
A.

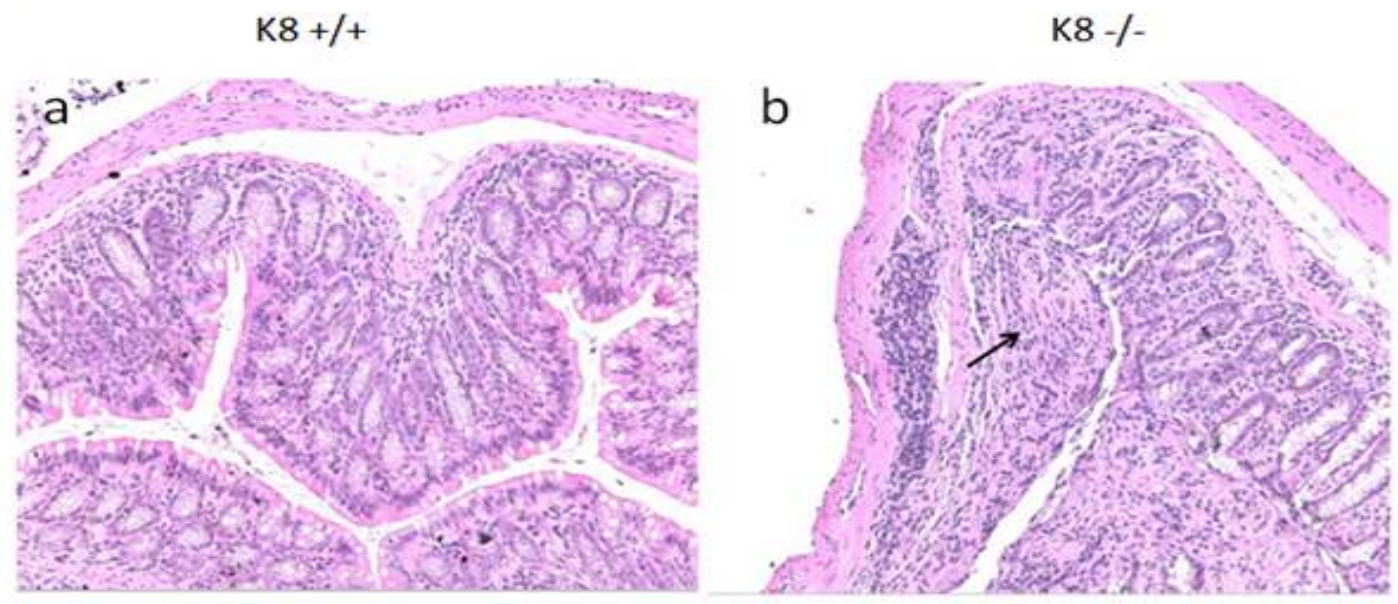

B.

control treated

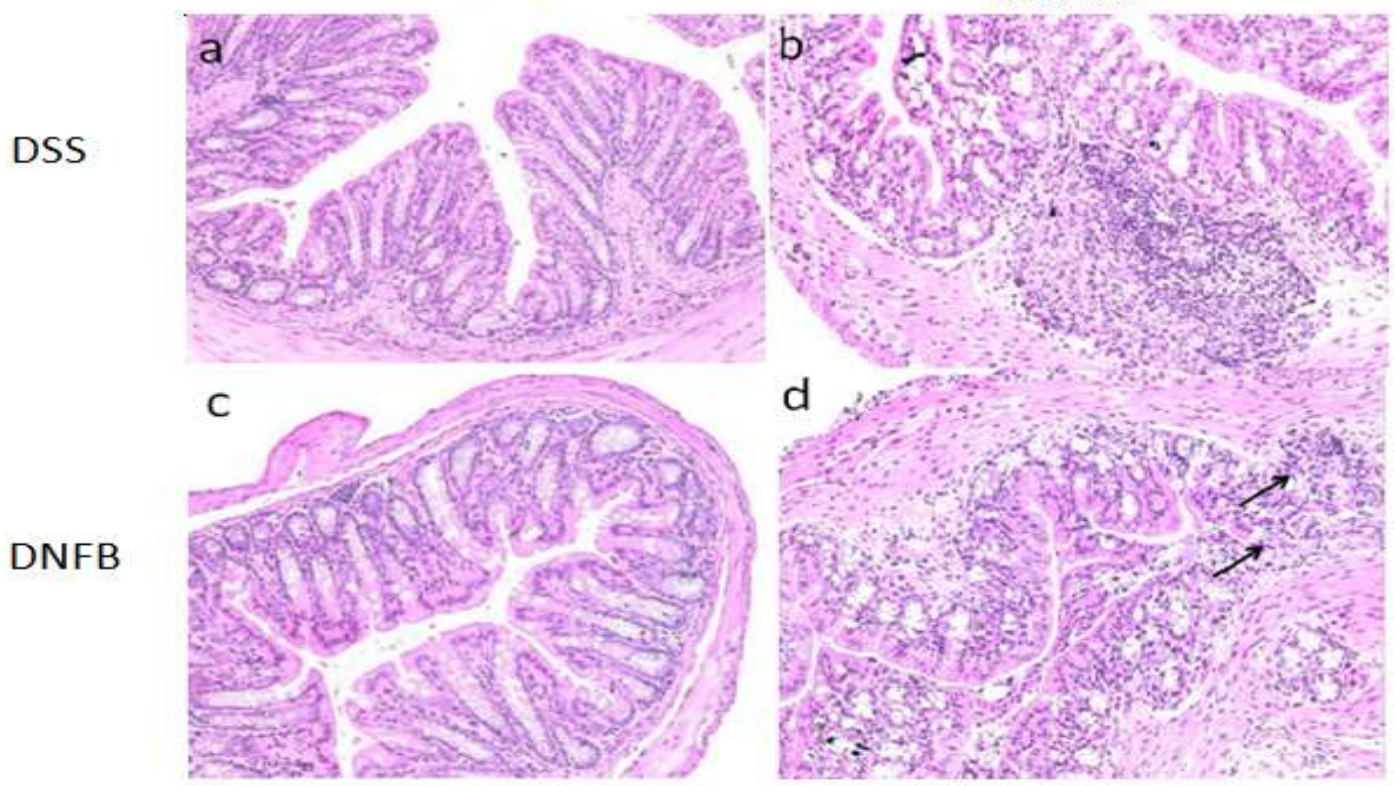

Figure 2. Hematoxylin and eosin (H\&E) staining of colitis and control mouse colons.

Sections (6 um in thickness) of OCT-embedded colon tissue from K8+/+ and K8-/- mice

(A), 5\% DSS treated and control mice (B: a and b) and DNFB and vehicle-sensitized animals (B: c and d) were stained with H\&E. The staining shows increased areas of inflammation in colitic mouse colons (arrows). 
To investigate differences in MC numbers between the colitis models, we used a chloroacetate esterase (CAE) staining protocol described by Rijnierse and co-workers (2006) to identify MCs in colons of DNFB-sensitized mice. Consistent with this group's findings, there was a modest increase in CAE + cells in the colon of DNFB-sensitized mice as compared to vehicle-sensitized controls (Figure 3B, c and d). Interestingly, a marked increase in MCs was noted in K8-/- as compared to DNFB-sensitized and K8+/+ colons (Figure 3A). The increase in MCs was more prominent in proximal colons of K8/- mice (Figure 3A, b and d). As expected, no increase in MC number was noted in DSSinduced colitis as compared to non-DSS treated mice (Figure 3B, a and b). 


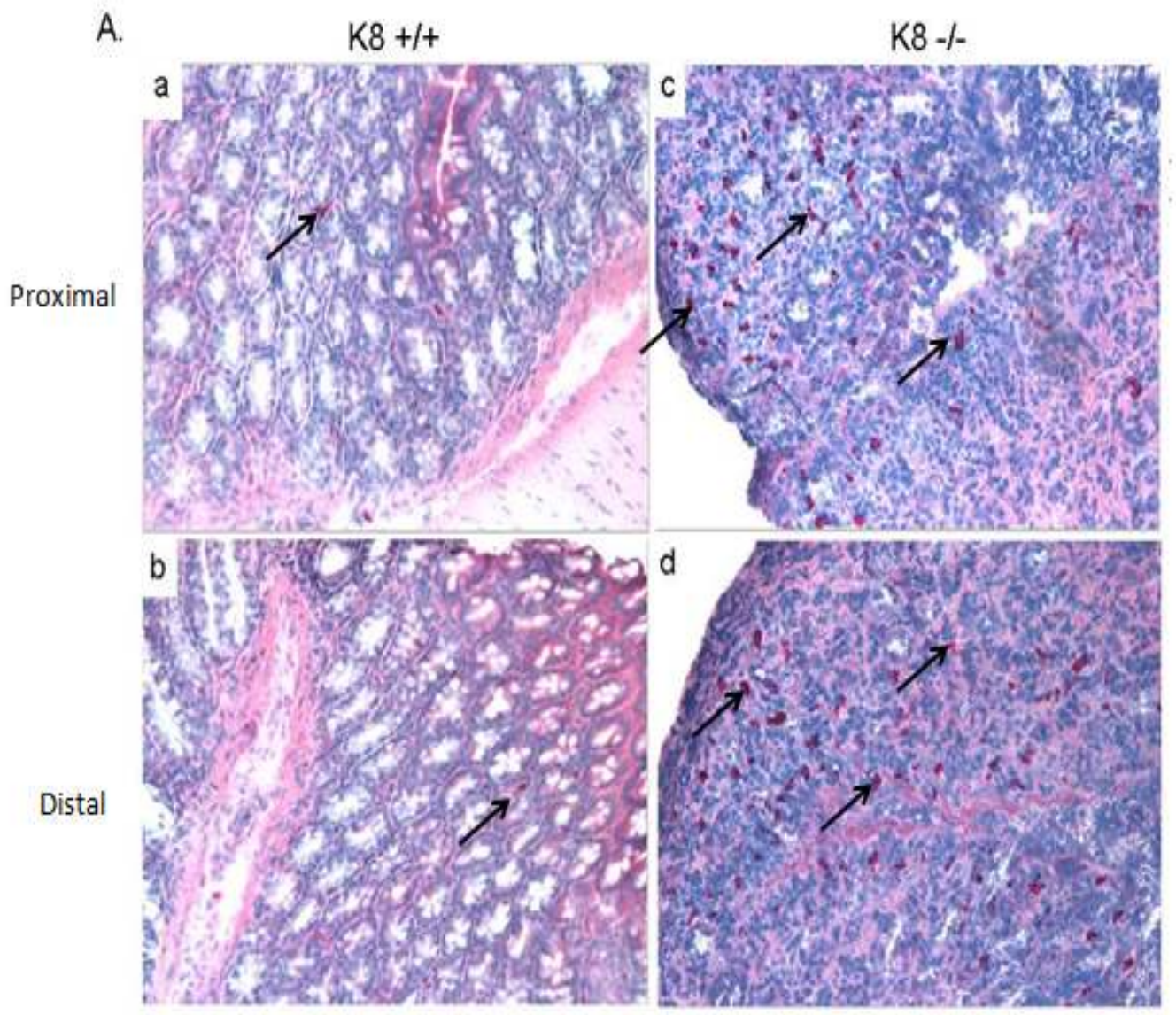

Figure 3A. Mast cell (MC) identification using CAE staining. OCT-embedded colon sections harvested from K8-/- and K8+/+ mice (A, above), DNFB- and DSS-treated and control mice (B, next page) were stained with $\mathrm{CAE}$ as described in the methods section. Note markedly increased CAE+ cells (arrows) in proximal and distal colons of K8-/- (A: $\mathrm{b}$ and $\mathrm{d})$ as compared to $\mathrm{K} 8+/+(\mathrm{A}$ : a and $\mathrm{c})$ mouse colons. 
B.

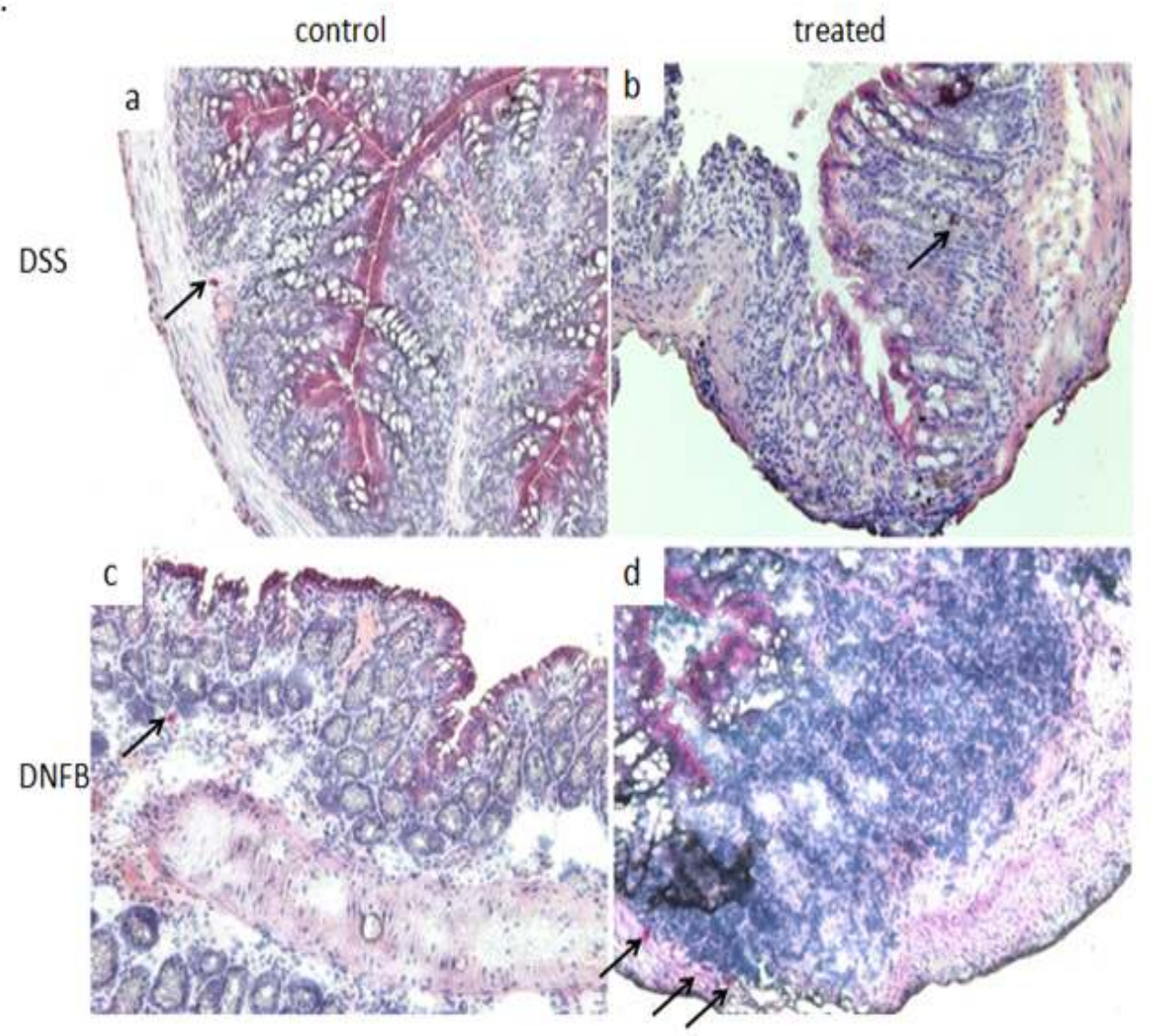

Figure 3B. Mast cell (MC) identification using CAE staining. OCT-embedded colon sections harvested from $\mathrm{K} 8-/-$ and $\mathrm{K} 8+/+$ mice (A, previous page), DNFB- and DSStreated and control mice (B, above) were stained with CAE as described in the methods section. 


\section{K8-null mice have higher expression of colon MC proteases}

In mice, several neutral mMCPs have been defined based on mRNA sequences.

mMCP-1, $-2,-4,-5$, and -9 are chymases, and mMCP-6 and -7 are tryptases $[12,32,13]$. To assess mRNA expression of mMCPs in K8-/- and K8+/+ colons, we used RT-PCR using mMCP specific primers (Table 2). Consistent with the increase in MC number in K8-/- colons (Figure 3A), K8-/- as opposed to K8+/+ colons had increased mMCP mRNA regardless of the mMCP type tested (Figure 4). mMCP-7 was most up-regulated compared to the other mMCP tested.

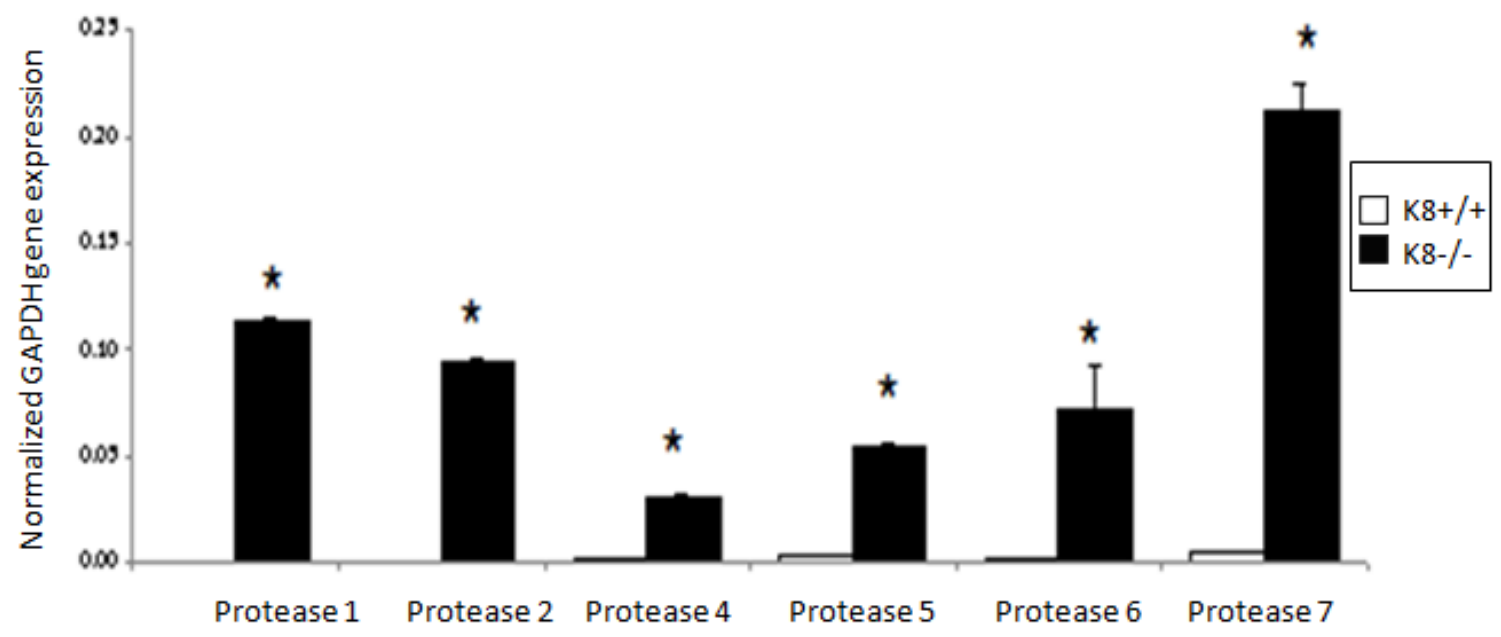

Figure 4. RT-PRC analysis of mast cell proteases (mMCP) in $\mathrm{K} 8+/+$ (white bars) and K8-/- (black bars) mice colons. Note up-regulation of mMCP 1,2,4,5,6, and 7 in the K8/- as compared to $\mathrm{K} 8+/+$ colon. The data are presented as mean relative to GAPDH expression \pm s.e.m. $(\mathrm{n}=3)$. ${ }^{*} \mathrm{p}<0.05$ when comparing $\mathrm{K} 8+/+$ with $\mathrm{K} 8$-/-. 
Chymases and tryptases are mast cell specific proteases that have long been used as reliable markers of $\mathrm{MC}$ degranulation [8]. To confirm the mRNA results above and to examine the expression of $\mathrm{MC}$ chymases and tryptases, western blot analysis was conducted in the three groups of mice: K8-null mice, DNFB and DSS-treated mice, and their control counterparts. As shown in Figure 5, K8-null mice had the highest expression of both chymase and tryptase as compared to their wildtype controls and the two chemically induced colitis model colons. In contrast to colons from DSS-treated mice, DNFB-sensitized mice had significant increase in chymase and tryptase. Absence or presence of $\mathrm{K} 8$ was confirmed using $\mathrm{K} 8$ antibody, and an actin antibody was used to confirm equal loading (Figure 5). 


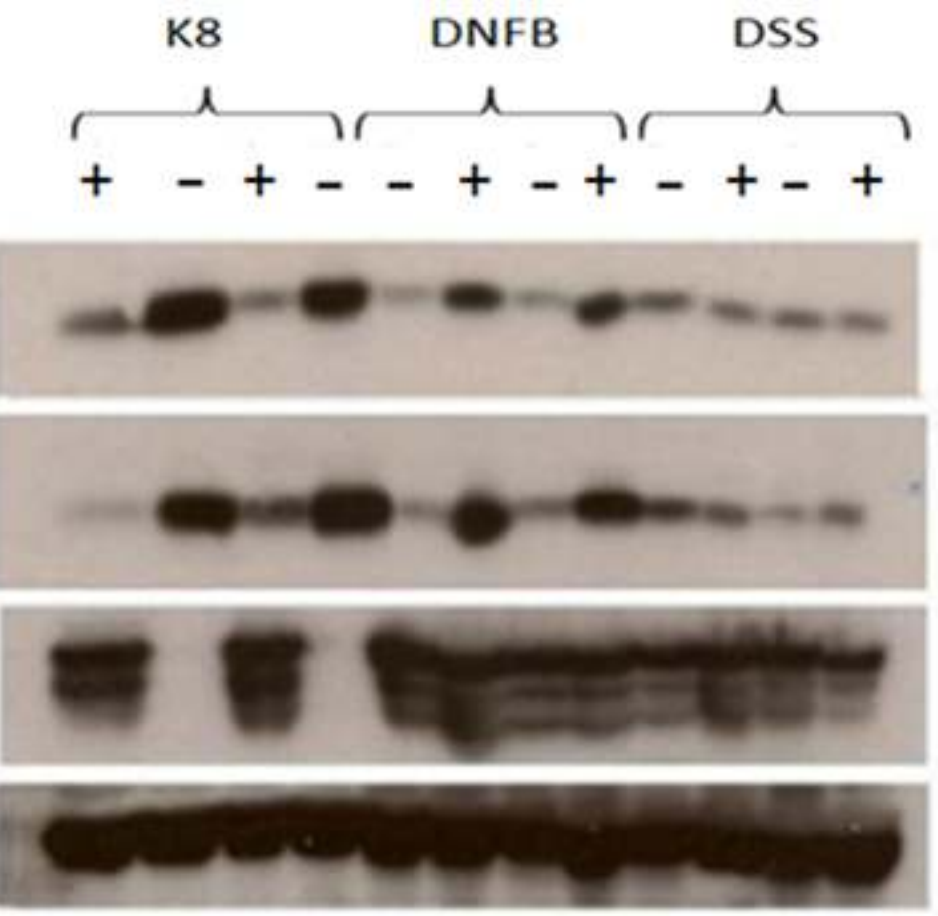

\section{Chymase}

Tryptase

Keratin 8

Actin

Figure 5. Colon expression of chymase and tryptase level between the different colitis models. Equal amounts of total colon lysates were separated by SDS page and then immunoblotted with anti-chymase, -tryptase, -keratin 8 , and -actin antibodies. Note that K8 -/- mice colons overexpress chymase and tryptase. Mice treated with DNFB (+) also had significantly increased chymase and tryptase expression as compared to colons from DSS-treated mice. 


\section{Discussion}

Mast cells have been long thought to have potential harmful effects because of their well defined role in atopic diseases, and because they cause many of the symptoms associated with allergic as well as immediate hypersensitivity reactions [33]. However, recent studies support a role for MCs in the sensitization to allergens as shown by the ability of early released MC tryptase to break down IgE, the key maker of allergic inflammation [7, 34]. Mast cells also contribute to the innate immune defense against bacterial and parasitic infections [34], and even enhance survival during venom poisoning [35]. In addition, MCs via the release of IL-10 can limit contact dermatitis and UVirradiation mediated inflammation and tissue injury [34]. On the other hand, MCs are thought to contribute to disease pathogenesis in chronic inflammatory and autoimmune diseases such as rheumatoid arthritis, multiple sclerosis and cardiovascular disease [7]. However, whether MCs play an important role in IBD remains poorly defined.

MCs are reported to be increased in colons of patients with IBD [36]. Not only does the number of MCs change, but the content of these cells can vary as well [37]. The role of MCs in IBD has been studied in chemically induced colitis models. However, it is uncertain whether MCs play a role in the trinitrobenzene sulfonic acid (TNBS) colitis model, because there is no difference in colonic disease between MC-deficient rats and wildtype controls exposed to TNBS [38]. On the other hand, in a more recent study, Rijnierse et al. (2006) reported an increase in MCs and a role for MCs in the dinitrofluorobenzene (DNFB)-induced model of colitis. Minocha and co-workers (1995) did not find a role for MCs in DSS colitis. Thus, in this study, we compared the number 
and characteristics of MCs in a non-chemically induced model of colitis, the K8-/chronic spontaneous model of colitis with a primary epithelial cell defect. K8-/- colons have a remarkable MC infiltration even in comparison to the defined DNFB-treated colons. MCs are tissue-resident cells originating from bone marrow. They migrate into tissues as immature committed progenitors where they complete their differentiation under the influence of microenvironmental factors [39]. Mature MCs can be very long lived and can retain their ability to proliferate particularly in the setting of inflammation [8]. Thus, the increase in MCs in K8-/- colons could be from increased recruitment and/or proliferation, although this hypothesis awaits further investigation.

When mast cells mature, they acquire numerous electron dense cytoplasmic granules. Once activated following an appropriate stimulus, mast cells degranulate and release their mediators. In this process, many preformed inflammatory mediators are released, including preformed cytokines such as TNF $\alpha$, histamine, proteoglycans, and several MCPs: also called chymases, tryptases, and carboxypeptidase A [40]. Tryptases and chymases belong to the serine protease class, and the designation of the specific MCP as chymases and tryptases relates to their substrate specificities. Tryptases are trypsin-like enzymes, while chymases are chymotrypsin-like enzymes [41]. We found an over-expression of MCPs in K8-/- colons by RT-PCR, which corresponded with increased chymase and tryptase protein levels. Such increase was higher in the K8-/- as compared to DNFB-treated colons, and is likely related to the increase in MC number. Rijnierse's group [42] argued the conflicting MC results in the TNBS-colitis model as opposed to their DNFB-mediated model may be from the higher concentration (50\%) of 
ethanol used as vehicle in the TNBS-colitis model that can induce inflammation in a MCindependent manner, and mask the TNBS/hapten-specific induced response. Our results in DSS-treated colons are consistent with those reported previously [26]. Mucosal breach with 5\% DSS over 7-8 days may not be a sufficient stimulus to mediate MC-dependent immune response.

In conclusion, absence of $\mathrm{K} 8$ is associated with a chronic colitis with marked MCs infiltration. Consistent with the increase in MCs, increased expression of MCPs are noted at the mRNA and protein levels. Presence of MCPs are good predictors of MC degranulation, and whether there is enhanced secretion of MC mediators in the K8-/colitis model remains to be tested. In addition, whether MCs play a role in disease pathogenesis in this model will also need further investigation. 


\section{References}

1. Galli, S. J., J. Kalesnikoff, M. A. Grimbaldeston, A. M. Piliponsky, C. M. Williams, and M. Tsai. 2005. Mast cells as "tunable" effector and immunoregulatory cells: Recent advances. Annu. Rev. Immunol. 23: 749-786.

2. Sonoda,T., Y. Kitamura, Y. Haku, H. Hara, and K. J. Mori. 1983. Mast-cell precursors in various hematopoietic colonies of mice produced in vivo and in vitro. Br. J. Haematol. 53: 611-620.

3. Kitamura, Y. 1989. Heterogeneity of mast cells and phenotypic change between subpopulations. Annu. Rev. Immunol. 7: 59-76.

4. Otsuka, H., J. Denburg, J. Dolovich, D. Hitch, P. Lapp, and R.S. Rajan. 1985. Heterogeneity of metachromatic cells in human nose: Significance of mucosal mast cells. J. Allergy. Clin. Immunol. 76: 695-702.

5. Dimitriadou, V., A. Rouleau, M.D. Trung Tuong, G.J. Newlands, H.R. Miller, G. Luffau, J.C. Schwartz, and M. Garbarg. 1997. Functional relationships between sensory nerve fibers and mast cells of dura mater in normal and inflammatory conditions. Neuroscience. 77: 829-839.

6. Walls A.F., S.H. He, M.G. Buckley, and A.R. McEuen. 2001. Roles of the mast cell and basophil in asthma. Clin. Exp. Allergy. 1: 68-72.

7. Rao K. N., M. A. Brown.2008. Mast cells: multifaceted immune cells with diverse roles in health and disease. Ann. N Y Acad. Sci. 1143: 83-104.

8. He S. H. Key role of mast cells and their major secretory products in inflammatory bowel disease. 2004. World J Gastroenterol. 10: 309-318.

9. Metcalfe, D. D., D. Baram, and Y. A. Mekori. 1997. Mast cells. Physiol. Rev. 77: 1033-1079.

10. Chu, W., D. A. Johnson, and P. R. Musich. 1992. Molecular cloning and characterization of mouse mast cell chymases. Biochim. Biophys. Acta. 1121: 8387.

11. Huang, R., and L. Hellman. 1991. Cloning and structural analysis of a novel mouse mast cell specific serine protease, the MMCP-6: A connective tissue mast cell specific tryptase. In "Proceedings of XIV International Congress of Allergology and Clinical Immunology'” (A. L. de Wek, Ed.), p. 122. Hoerefe \& Huber, Kyoto, Japan. 
12. Reynolds, D. S., R. L. Stevens, W. S. Lane, M. H. Carr, K. F. Austen, and W.E. Serafin. 1990. Different mouse mast cell populations express various combinations of at least six distinct mast cell serine proteases. Proc. Natl. Acad. Sci. USA. 87: 3230-3234.

13. Hunt, J. E., D. S. Friend, M. F. Gurish, E. Feyfant, A. Sali, C. Huang, N. Ghildyal, Stechschulte S., K. F. Austen, and R. L. Stevens. 1997. Mouse mast cell protease 9 , a novel member of the chromosome 14 family of serine proteases that is selectively expressed in uterine mast cells. J. Biol. Chem. 272: 29158-29166.

14. Jippo T., K. Tsujino, H.M. Kim, D.K. Kim, Y.M. Lee, Y. Nawa, and Y. Kitamura. 1997. Am. J. Pathol. 150: 1373- 1382.

15. Friend D. S., N. Ghildyal, K.F. Austen, M.F. Gurish, R. Matsumoto, R.L. Stevens. 1996. J. Cell Biol. 135: 279- 290.

16. Aldenborg, F., and L. Enerback. 1985. Thymus dependence of connective tissue mast cells: a quantitative cytofluorometric study of the growth of peritoneal mast cells in normal and athymic rats. Int. Arch. Allergy Immunol. 78: 277-282.

17. Bienenstock, J. 1986. Mucosal immunological protection mechanisms in the airways. Eur. J. Respir. Dis. 147: 61-71.

18. Irani A. A., N. M. Schechter, S. S. Craig, L. Ashman, T. Ishizaka, K.M. Zsebo and L. B. Schwartz. 1986. Two types of human mast cells that have distinct neutral protease composition. Proc. Natl. Acad. Sci. USA. 83: 4464-4468.

19. Holgate, S.T., C. Robinson and M.D. Church. 1988. Mediators of immediate hypersensitivity. In Allergy, Principles and Practice, J. Pathophysiology of heart failure and the renin-angiotensin- p. 267-301.212.

20. Lakatos, L. 2000. Immunology of inflammatory bowel diseases. Acta. Physiol. Hung. 87: 355-372.

21. Bouma, G., and W. Strober. 2003. The immunological and genetic basis of inflammatory bowel disease. Nat. Rev. Immunol. 3: 521-533.

22. Strober, W., I.J. Fuss, and R.S. Blumberg. 2002. The immunology of mucosal models of inflammation. Аnпu. Rev. Immunol. 20: 495-549.

23. Baribault, H., J. Penner, V. Iozzo, and M. Wilson-Heiner. 1994. Colorectal hyperplasia and inflammation in keratin 8-deficient FVB/N mice. Genes Dev. 8: 2964-2973. 
24. Toivola D.M., Krishnan S., Binder H.J., Singh S.K., and Omary M.B. 2004. Keratins modulate colonocyte electrolyte transport via protein mistargeting. J. Cell Biol. 164:911-21.

25. Habtezion A., D. M. Toivola, E. C. Butcher, and M. B. Omary. 2005. Keratin-8deficient mice develop chronic spontaneous Th2 colitis amenable to antibiotic treatment. J. Cell. Sci. 118:1971-80.

26. Minocha, A., C. Thomas, and R. Omar. 1995. Lack of crucial role of mast cells in pathogenesis of experimental colitis in mice. Dig. Dis. Sci. 40: 1757-1762.

27. Toivola D. M., Baribault H., Magin T., Michie S. A., and Omary M. B. 2000. Simple epithelial keratins are dispensable for cytoprotection in two pancreatitis models. Am. J. Physiol. Gastrointest. Liver. Physiol. 279: 1343-1354.

28. Rijnierse, A., A.S. Koster, F.P. Nijkamp, and A.D. Kraneveld. 2006. Critical role for mast cells in the pathogenesis of 2,4-dinitrobenzene-induced murine colonic hypersensitivity reaction. J. Immunol. 176: 4375-4384.

29. Tao G. Z., D. M. Toivola, B. Zhong, S. A. Michie, E. Z. Resurreccion, Y. Tamai, M.M. Taketo, M. B. Omary. 2003. Keratin-8 null mice have different gallbladder and liver susceptibility to lithogenic diet-induced injury. J Cell Sci. 116: 4629-38.

30. Li M., K. Liu, J. Michalicek, J. A. Angus, J. E. Hunt, L. J. Dell'Italia, M. P. Feneley, R. M. Graham, and A. Husain. 2004. Involvement of chymase-mediated angiotensin II generation in blood pressure regulation. J. Clin. Invest.114: 112-20.

31. Funaba M., T. Ikedab, M. Murakamic, K. Ogawad, and M. Abe. 2004. Upregulation of mouse mast cell protease- 6 gene by transforming growth factor- $\beta$ and activin in mast cell progenitors. Cell Signal. 17: 121-8.

32. McNeil, H. P., D. S. Reynolds, V. Schiller, N. Ghildyal, D. S. Gurley, K. F. Austen, and R. L. Stevens. 1992. Isolation, characterization, and transcription of the gene encoding mouse mast cell protease 7. Proc. Natl. Acad. Sci. USA. 89: 11174-11178.

33. Yu M., M. Tsai, S.Y. Tam, C. Jones, J. Zehnder, and S.J. Galli. 2006. Mast cells can promote the development of multiple features of chronic asthma in mice. $J$. Clin. Invest. 116: 1633-1641.

34. Kalesnikoff J., S. J. Galli. 2008. New developments in mast cell biology. Nat Immunol. 9: 1215-23. 
35. Metz, M., A.M. Piliponsky, C.C. Chen, V. Lammel, M. Abrink, G. Pejler, M. Tsai, and S.J. Galli. 2006. Mast cells can enhance resistance to snake and honeybee venoms. Science. 313: 526-530.

36. Nishida Y., K. Murase, H. Isomoto, H. Furusu, Y. Mizuta, R. H. Riddell, S. Kohno. 2002. Different distribution of mast cells and macrophages in colonic mucosa of patients with collagenous colitis and inflammatory bowel disease. Hepatogastroenterology. 49: 678-82.

37. Stoyanova, I. I., and M. V. Gulubova. 2002. Mast cells and inflammatory mediators in chronic ulcerative colitis. Acta. Histochem. 104: 185-192.

38. Fukumoto Y., H. Kasai, H. Takahashi, H. Sugiyama, N. Hase and H. Kaneko. 2002. The role of mast cells in the development of 2, 4, 6-trinitrobenzene sulfonic acid-induced colitis in rats. Scand. J. Gastroenterol. 37: 555-560.

39. Okayama Y., T. Kawakami. 2006. Development, migration, and survival of mast cells. Immunol Res. 34: 97-115.

40. Gordon, J.R., P. R. Burd, S. J. Galli. 1990. Mast cells as a source of multifunctional cytokines. Immunol. Today. 11: 458-464.

41. Chandrasekharan, U. M., S. Sanker, M. J. Glynias, S. S. Karnik, and A. Husain. 1996. Angiotensin II-forming activity in a reconstructed ancestral chymase. Science. 271: 502-505.

42. Rijnierse, A., F. Nijkamp, and A. Kraneveld. 2007. Mast cells and nerves tickle in the tummy Implications for inflammatory bowel disease and irritable bowel syndrome. Pharmacology \& Therapeutics 116: 207-235. 